ECONOMICS

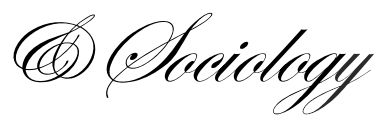

Emília Dul'ová Spišáková, University of Economics in

Bratislava,

Bratislava, Slovakia,

E-mail:emilia.spisakova@euke.sk

Barbora Gontkovičová,

University of Economics in

Bratislava,

Bratislava, Slovakia,

E-mail:

barbora.gontkovicova@enke.sk.

Zuzana Hajduová,

University of Economics in

Bratislava,

Bratislava, Slovakia,

E-mail:zuzana.hajduova@enke.sk

Received: January, 2016

1st Revision: March, 2016

Accepted: May, 2016

DOI: $10.14254 / 2071-$

789X.2016/9-2/18

JEL Classification: I24, I25, O15
Dul'ová Spišáková, E., Gontkovičová, B., Hajduová, Z. (2016), Education from the Perspective of the Europe 2020 Strategy: the Case of Southern Countries of the European Union, Economics and Sociology, Vol. 9, No 2, pp. 266-278. DOI: 10.14254/2071-789X.2016/9-2/18

\section{EDUCATION FROM THE PERSPECTIVE \\ OF THE EUROPE 2020 STRATEGY: THE CASE OF SOUTHERN COUNTRIES OF THE EUROPEAN UNION}

\begin{abstract}
Europe 2020 is the growth strategy of European Union for the coming decade. Education is one of the objectives of this strategy. Its fulfillment is quantified through two indicators, namely the rate of early school leavers and population with tertiary education. The aim of this paper is to analyse and assess the level of achievement of these two sub-objectives in the Member States in 2014, with the emphasis on the southern countries of the European Union as well as to estimate the the degree of fulfillment, respectively failure of the target values until the year 2020 .
\end{abstract}

\title{
Introduction
}

Keywords: early leavers from education, education, Europe 2020, target, tertiary educational attainment.

Until recently, the question of economy's competitiveness was covered by the Lisbon Strategy for growth and jobs, the primary target of which was, that the European Union should become until 2010 the most competitive and most dynamic knowledge-based economy in the world, capable of sustainable economic growth in which there will be more and better jobs and greater social cohesion (Ministry of Finance SR, 2005). In 2010 the Lisbon Strategy was successed by a new strategy developed by the European Commission and called Europe 2020. As in the Lisbon Strategy, also in Europe 2020, the European Commission identified key targets the fulfilment of which, until the year 2020, will contribute to the desired growth and progress in individual Member States, as well as in the European Union overall. The Strategy includes the five following targets (European Commission, 2010):

- Employment - 75\% of the 20-64 year-olds should be employed;

- $\quad \mathrm{R} \& \mathrm{D}-3 \%$ of the European Union's GDP should be invested in R\&D; 
- Climate change/energy - this objective includes three sub-objectives: greenhouse gas emissions should be $20 \%$ (or even $30 \%$, if the conditions are right) lower than in 1990; $20 \%$ of energy should be from renewable; energy efficiency should increase by about $20 \%$;

- Education - this objective includes two sub-objectives expressed by two indicators, namely the rate of early school leavers and population with tertiary education. The first indicator concerns the reduction of early leaving education rate and training of population aged 18 to 24 years below 10\%. The second indicator expresses the increase of the population aged 30-34 years who have completed tertiary education for the minimum of $40 \%$ in this age group;

- Poverty/social exclusion - in the European Union there should be at least 20 million fewer people in or at risk of poverty and social exclusion.

The fourth target concerning education isin the focus of our analysis here. Every year, 6 million young Europeans leave school with at best lower secondary education. This currently represents $14 \%$ of the 18-24-year-olds, which in turn fuels high levels of youth unemployment (European Commission, 2014b). This is why the European Commission is trying to reduce the number of early school leavers and increase the number of people with tertiary education. The southern countries of the European Union belong according to the most actual Eurostat data among the countries with the highest rate of youth unemployment.

In this paper we will analyse the current state of achieving the established targets with the emphasis on the southern countries of the European Union and explore by using regression analysis the estimated development of the related indicators untill 2020.

\section{Theoretical Framework}

The Europe 2020 presents an ambitious and comprehensive strategy to guide the EU out of the economic crisis, to ensure macroeconomic stability and to put in place an ambitious structural reform agenda. An essential part of this strategy is the introduction of reforms with a medium - term to long - term horizon that focus on promoting the sustainability of public finances, enhancing potential growth and realising the 2020 objectives (Hobza \& Mourre, 2010).

Relevance of defined objectives is criticized and their interconnectedness is being discussed. Feasibility of achieving the objectives is a basic issue for the successful fulfillment of the objectives. This issue is solved by Colak and Ege (2013), but also by Leschke, Theodoropoulou, Watt (2012). Roth and Thum (2010) pointed out that the objectives in the area of education are very ambitious and almost impossible to fulfill in a given time horizont.

Despite numerous critics, the Europe 2020 was adopted and implemented at the national level. Attention and efforts should therefore focus on fulfillment the objectives at the national level.

It is important that European policy-makers understand that the quantity and quality of education will play a key role in maintaining European competitiveness. The creation of knowledge societies in which knowledge creation among citizens is given top priority would be the appropriate step to unleash the creativity so badly needed for Europe's future wealth (Roth \& Thum, 2010).

Europe 2020 is the European Union's ten-year jobs and growth strategy. It was launched in 2010 to create the conditions for smart, sustainable and inclusive growth. Among its headline targets, two are related to education to monitor access to the labour market and employability: increasing the proportion of persons having completed tertiary education and reducing the share of early leavers from education and training (European Commission, 2015b). 
Education can be characterized as the sum of general and specialized, theoretical and practical knowledge, which man purposefully obtained during training (Matulčíková, Matulčík, 2012). It brings many benefits not only to the personal life of the individual, but for society as a whole, for example:

- Education leads to personal development and growth of the society,

- Education brings effect of satisfaction and benefits of consumption,

- Higher education = better luck,

- Education brings positive effect on the welfare of others,

- Education increases productivity and economic performance (Dudová, 2009).

In Figure 1 we can see the interdependencies of factors that influence the area or that are influenced by the area "Education" in the strategy Europe 2020.

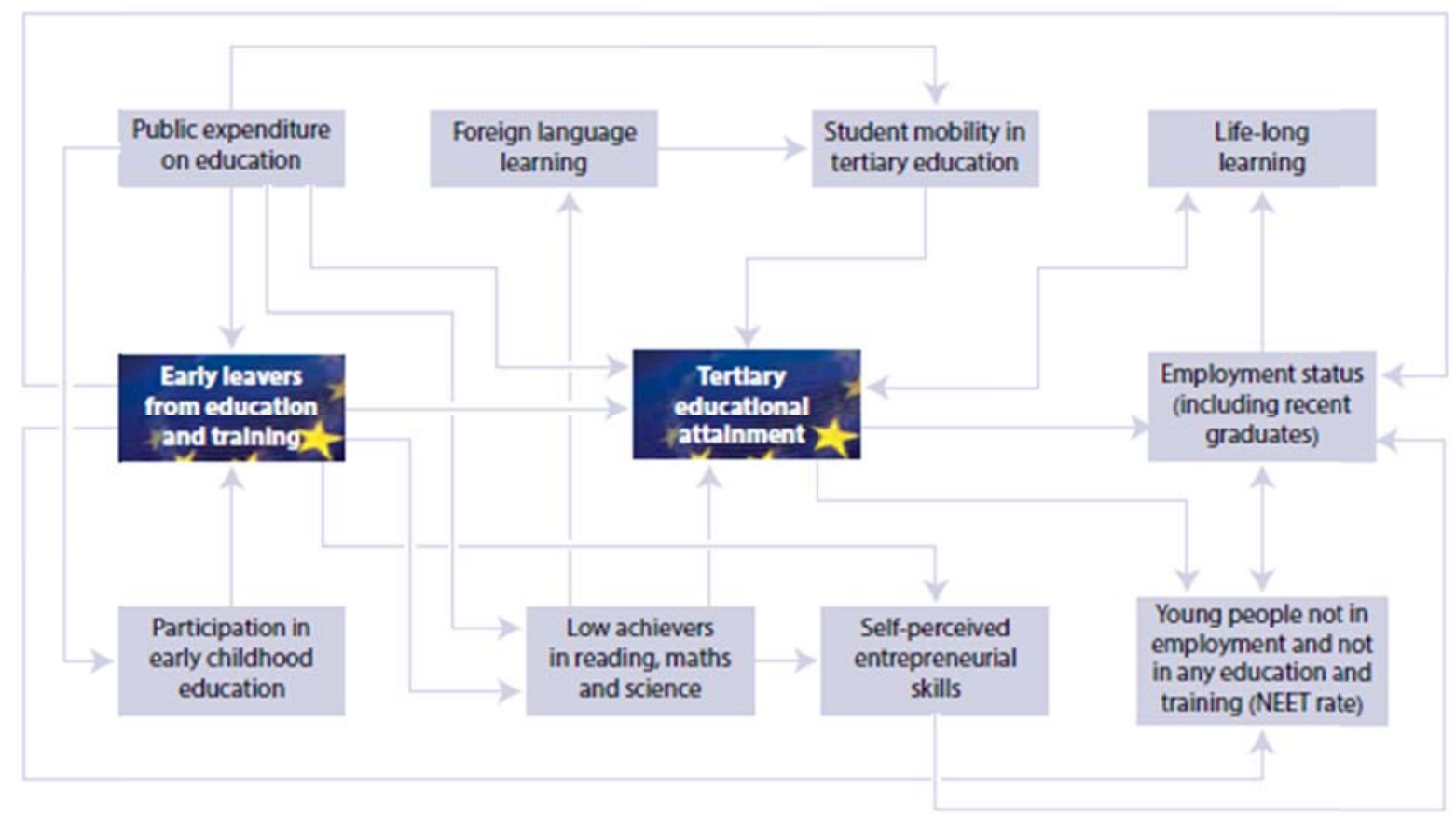

Figure 1. The factors that influence the area or that are influenced by the area "Education" Source: European Commission, 2013.

Public expenditures are the important factor affecting the level off education in each country. They affect the level of education in compulsory education, but also the level of education at universities. Low expenditure on education increased the number of people who can show weaker performance in reading, counting and science, given that schools don't have sufficient financial resources to enlarge the school premises, but also for the purchase of school supplies (Marlier \& Natali, 2010). The weaker performance in reading and counting reduces the chance of getting higher education and learning of foreign languages, which result (at best) in low-wage jobs or (at worst) in the unemployment (European Commission, 2013). Nowadays, the knowledge of a foreign language belongs to the priorities of international communication, education, culture, science and social disciplines around the world and also to the key competences in applying for quality jobs in the labor market. Young people can strengthen their employability and personal development through participation on mobility at university. The current labor market has very high claims on the applicants, so it is necessary to develop the knowledge, skills and abilities throughout life, thereby enhancing the importance of lifelong learning (Dolinská, 2014). The aforementioned factors in varying degrees affect the possibility of completing tertiary education. Consequently, successfully 
completed a tertiary education significantly increases the chances of getting a job with a higher income.

\section{Research Methodology}

Methods used in the elaboration of the chapter are the most commonly used methods of economic research, and they are based on the aim and structure of the article. These are general methods such as analysis, spatial comparison and trend comparison, synthesis, induction, deduction and mathematical - statistical methods. For the simulation of estimated growth of indicators until the year 2020, we will use the regresion analysis.

From a number of functions describing the current development of the indicators and their anticipate development in 2020 (linear, exponential, logarithmic, polynomial function and others) we choose the one that will have the highest coefficient of determination (i.e. the highest probability of achieving simulated values in the future). For these calculations we use MS Excel. The suitability of trend function is checked by the Coefficient of Determination, $\mathrm{F}$ test and the P-value.

$\mathrm{P}$-value assesses the significance of individual regression coefficients. If the p-value is less than 0.05, regression coefficient is significant, higher value than 0.05 indicates nonsignificance. The significance is required to assume for each estimated regression coefficient separately. While Coefficient of Determination (R-squared) provides an estimate of the strength of the relationship between proposed model and the response variable, it does not provide a formal hypothesis test for this relationship. The overall F-test determines whether this relationship is statistically significant. Similar to the assessing the significance of individual regression coefficients, again, if the value is below 0.05 , the model as a whole is statistically significant. If the P value for the overall F-test is less than your significance level, you can conclude that the R-squared value is significantly different from zero.

For analysis, comparison and realization of regresion analysis will be used statistics of Eurostat (to the date 15th of December, 2015) and also official documents of the European Union. The time period for which the countries are compared and analyzed is 2002-2014.

\section{Result and Discussion}

This chapter includes the description and evaluation of fulfillment of the two subobjectives in education. Subsequently, prediction of state in 2020 highlights possible and estimated development of indicators so that the individual southern countries of the European Union achieved the target values until the year 2020.

\subsection{Early leavers from education and training}

From the group of eight indicators set by the European Commission for the Europe 2020, the two indicators dealing with issues of education. The first described indicator monitors the percentage of the population that early leaves form education and training. According to the set target the rate of early school leavers (population in the age group 18-24 years) would reduce fewer than $10.0 \%$ by 2020 .

Figure 2 shows the evolution of the indicator for the thirteen-year period in the European Union, but also the proportion of women and men that early leave education and training. 


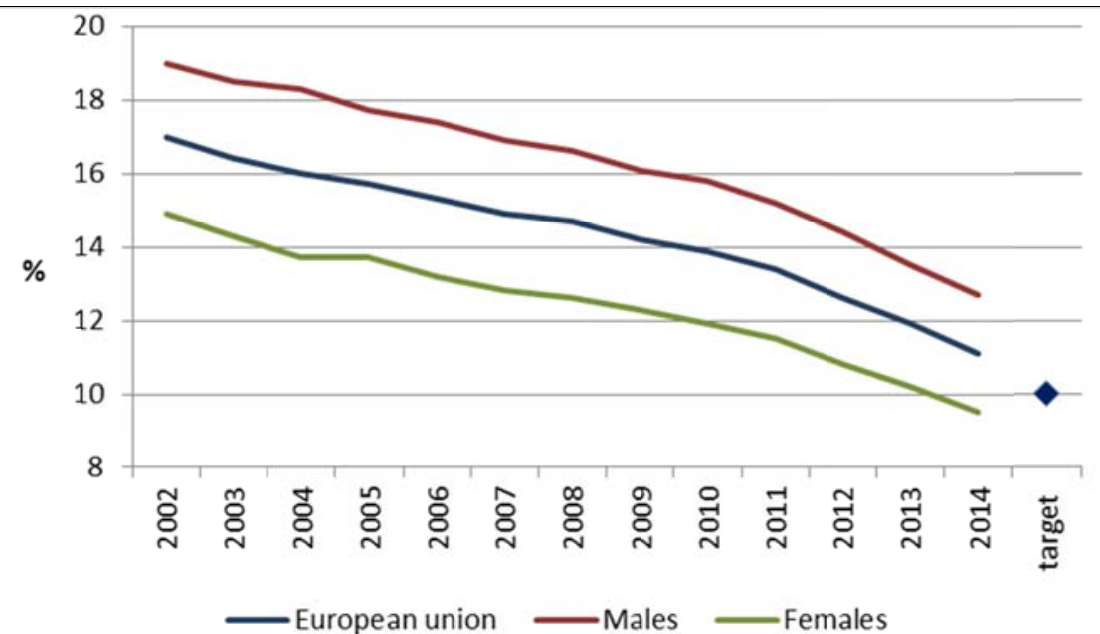

Figure 2. Evolution of the percentage of the population aged 18-24 years who early leave education and training in the European Union

Source: compiled by authors according to data from Eurostat.

Figure 3 shows the differences in the values of the monitored indicator between member countries of the European Union in 2002 and 2014 and compares the values obtained with the targets of countries, that should be achieved no later than 2020. For each country the national targets are appropriate to the conditions and development of the country in previous periods.

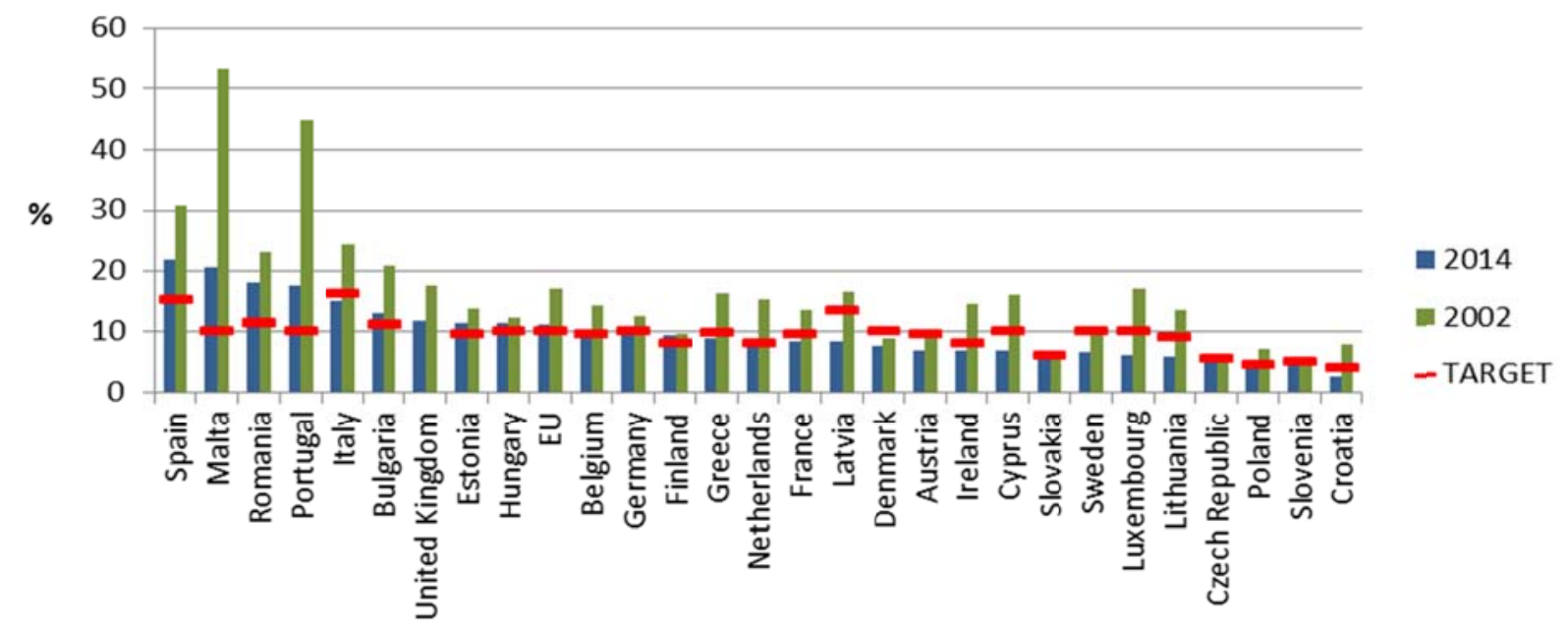

Figure 3. Percentage of population aged 18-24 years who leave education and training in the European Union in 2002, 2014, compared with a target value Source: compiled by authors according to data from Eurostat.

In 2014 was the highest percentage of people prematurely leave education and training in Spain (23.6\%), Malta and Portugal. In these two countries was observed in thirteen years recorded the largest decline of indicator (Malta decreased from 53.2\% in 2002 to 20.8\%, in Portugal from $45.0 \%$ to $18.9 \%$ ). The most behind the target value was in 2014 Malta (10.4\%), Portugal (7.4\%), Spain (6.9\%) and Romania (6.8\%). On the contrary, some countries have already achieved this sub-objective of the strategy. The best is Latvia, whose value is 4.9\% lower than the stated target value and Luxembourg (3.9\%). Than follow Sweden, 
Cyprus and Lithuania with values of less of $3.1 \%$ to $3.3 \%$. The positive is fact, that the number of countries, which already achieved this sub-objective rise from 8 countries in 2013 to 16 countries in 2014.

Evolution of the share of population aged 18-24 years, which early leave education and training to the total population in that age group in the southern countries of the European Union in the years 2002-2014 captures Figure 4. Based on this picture it can be stated that there is in most cases noticeable systematic decrease of the monitored indicator. The southern coutries are divided into two groups based on fulfillment of the criterion.
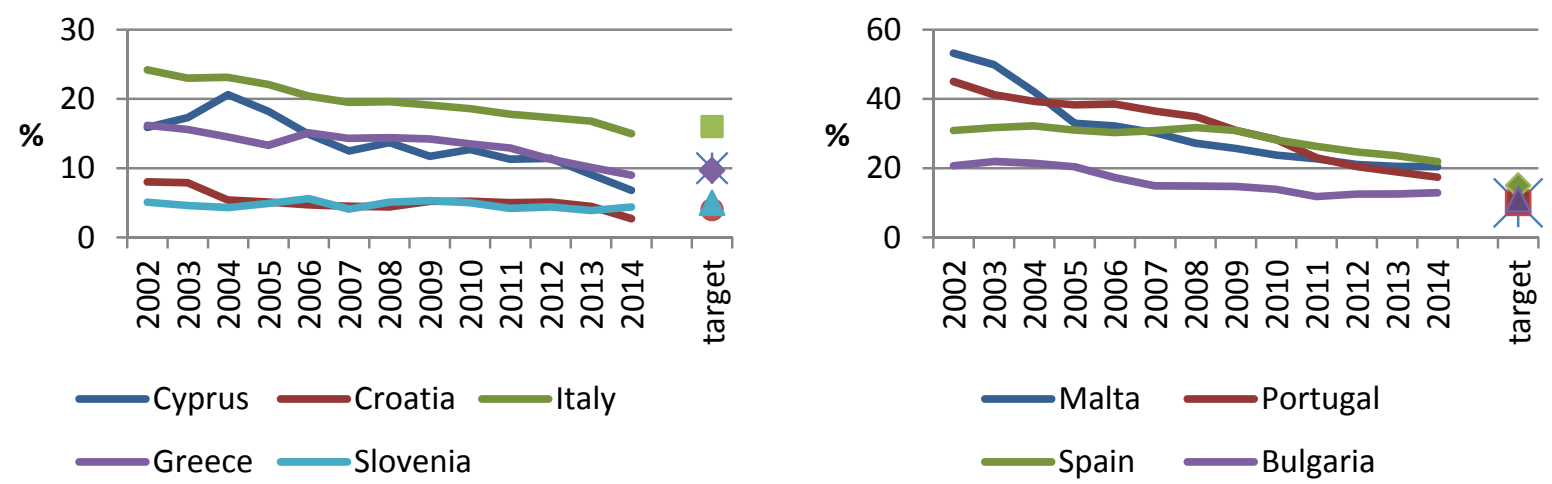

Figure 4. Evolution of the percentage of the population aged 18-24 years who early leave education and training in the southern countries of the European Union Source: compiled by authors according to data from Eurostat.

First group of countries (Cyprus, Croatia, Italy, Greece and Slovenia) consists from countries which achieved the stated objectives during monitored period. The best value reachs Slovenia, the criterion has already been achieved in 2003 for the first time and in 2014 even exceed the stated target of $5.0 \%$ by $0.6 \%$. Than follow Cyprus, which objective is to reduce early leaving of education and training of young people at $10.0 \%$. The country has already fulfilled this objective between the years 2012 and 2013, and in the last monitored year, the value of indicator decreased to $6.8 \%$. Remaining three countries - Croatia, Italy and Greece have fulfilled their objectives between the years 2013 and 2014. Malta, Portugal, Spain and Bulgaria are lagging behind in achieving that objective throughout whole monitored period. The target value of Malta and Portugal is identical to the Union target, e. i. $10.0 \%$ and with the comparison to 2014. Malta has to reduce this value most from the monitored countries by $10.4 \%$ and Portugal by $7.4 \%$. Spain lags behind the target $(15.0 \%)$ of $6.9 \%$. Bulgaria is the nearest to achieve the target $(11.0 \%)$ and needs to reduce the current value by $1.9 \%$.

Precisely for this reason, we visualized in Figure 5 estimated development of the monitored indicator of that four countries so that by 2020 the targets will be achieved in these countries. 


\section{INTERDISCIPLINARY APPROACH TO ECONOMICS AND SOCIOLOGY}
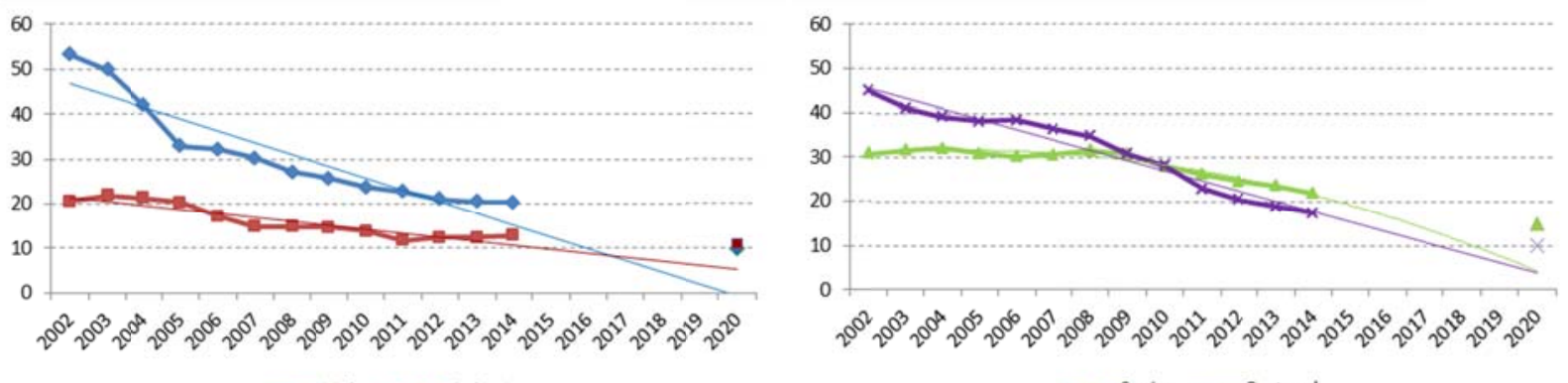

Figure 5. Estimated development of indicator until the year 2020

Source: compiled by authors.

Table 1. The estimated parameters of the regression model I

\begin{tabular}{|c|c|c|c|c|c|c|c|c|c|c|c|c|}
\hline & $\begin{array}{c}\text { Multiple } \\
\text { R }\end{array}$ & $\begin{array}{c}\mathrm{R} \\
\text { Square }\end{array}$ & $\begin{array}{l}\text { Adjusted } \\
\text { R Square }\end{array}$ & $\begin{array}{l}\text { Stand. } \\
\text { Error }\end{array}$ & $\begin{array}{c}\text { Significance } \\
\text { F }\end{array}$ & & $\begin{array}{l}\text { Coeffi } \\
\text { cients }\end{array}$ & $\begin{array}{l}\text { Stand. } \\
\text { Error }\end{array}$ & $t$ Stat & P-value & $\begin{array}{c}\text { Lower } \\
95 \%\end{array}$ & $\begin{array}{l}\text { Upper } \\
95 \%\end{array}$ \\
\hline \multirow{2}{*}{ Malta } & \multirow{2}{*}{0.9301} & \multirow{2}{*}{0.8652} & \multirow{2}{*}{0.8530} & \multirow{2}{*}{4.2340} & \multirow{2}{*}{ 4.08099E-06 } & Intercept & & & & $5.88 \mathrm{E}-10$ & 43.902 & 54.868 \\
\hline & & & & & & X Var.1 & -2.6 & 0.3 & -8.40 & $4.08 \mathrm{E}-06$ & -3.328 & -1.947 \\
\hline \multirow{2}{*}{ Bulgaria } & \multirow{2}{*}{0.9293} & \multirow{2}{*}{0.8636} & \multirow{2}{*}{0.8512} & \multirow{2}{*}{1.4408} & \multirow{2}{*}{$2.27101 \mathrm{E}-06$} & Intercept & 22.3692 & 0.8477 & 26.389 & $2.68 \mathrm{E}-11$ & 20.504 & 24.235 \\
\hline & & & & & & X Var. 1 & & 0.1068 & & E-06 & -1. & -0.656 \\
\hline \multirow{3}{*}{ Spain } & \multirow{3}{*}{0.9751} & \multirow{3}{*}{0.9509} & \multirow{3}{*}{0.9410} & \multirow{3}{*}{0.8480} & \multirow{3}{*}{ 2.8617E-07 } & & 30. & 0.8300 & 36.372 & -12 & 28. & 32.037 \\
\hline & & & & & & $\mathrm{X}$ Var. 1 & 0.8502 & 0.2727 & 3.118 & 0.010908 & 30.243 & 1.458 \\
\hline & & & & & & X Var. 2 & -0.1167 & 0.0190 & -6.160 & 0.000107 & $7-0.159$ & $-0,075$ \\
\hline \multirow{2}{*}{ Portugal } & \multirow{2}{*}{0.9799} & \multirow{2}{*}{0.9603} & \multirow{2}{*}{0.9567} & \multirow{2}{*}{1.9283} & & Intercept & 48.0615 & 1.1345 & 42.364 & $1.54 \mathrm{E}-13$ & 45.565 & 50.559 \\
\hline & & & & & & X Var.1 & -2.3308 & 0.1429 & -16.307 & $4.72 \mathrm{E}-09$ & -2.645 & -2.016 \\
\hline
\end{tabular}

Source: compiled by authors.

The future development of the indicator, we describe by the different trends. The most appropriate trend is given by the highest coefficient of Determination, Significance F and Pvalues (Table 1). The most appropriate trend of estimated development of indicator in three countries is a linear trend. For Spain is the most accurate trend of estimated development of indicator the polynomial trend of 2nd range (Table 2).

Table 2. Trends describing estimated development of the monitored indicator by 2020

\begin{tabular}{lll}
\hline Country & Trend & $\mathrm{R}^{2}$ \\
\hline Malta & $\mathrm{y}=-2.6374 \mathrm{x}+49.3846$ & 0.8652 \\
\hline Bulgaria & $\mathrm{y}=-0.8912 \mathrm{x}+22.2692$ & 0.8636 \\
\hline Spain & $\mathrm{y}=-0.1167 \mathrm{x}^{2}+0.8502 \mathrm{x}+30.1874$ & 0.9509 \\
\hline Portugal & $\mathrm{y}=-2.3308 \mathrm{x}+48.0615$ & 0.9603 \\
\hline
\end{tabular}

Source: compiled by authors.

If the value of the indicator in selected countries develope by the trend in Table 2, Bulgaria is expected to reach target value expressing the share of the population aged 18-24 years who early leave education and training in the total population alreadly in 2015 (9.89\%). Malta should achieve the target in 2016 (9.82\%), Spain in 2017 (13.91\%) and Portugal in 2018 (8.44\%). On this basis, we can conclude that if the indicator develops in the future according to the above functions, by 2020 all the selected countries should achieve their national targets. 


\subsection{Higher education}

The second sub-objective is the target in the field of higher education. It follows through indicator expressing the share of the population with a tertiary degree at age 3034 years in the total population of that age group. The target value of the monitored indicator, which should be achieved on average for the European Union, is $40.0 \%$.

Figure 6 shows the increasing share of the population aged 30-34 years in the European Union, who have completed tertiary education in the total population of that age group. Its value gradually increased from $23.6 \%$ in 2002 to $37.9 \%$ in 2014 .

The changes occurred in the evolution of the indicator in terms of gender, when in the 80 s and 90 s of the last century was predominant share of tertiary educated men over women, but during recent years the situation has changed. Throughout the thirteen-year period, the share of women with tertiary education aged 30 to 34 years on the total number of women in this age group higher than that of men. The difference is approximately $18.0 \%$.

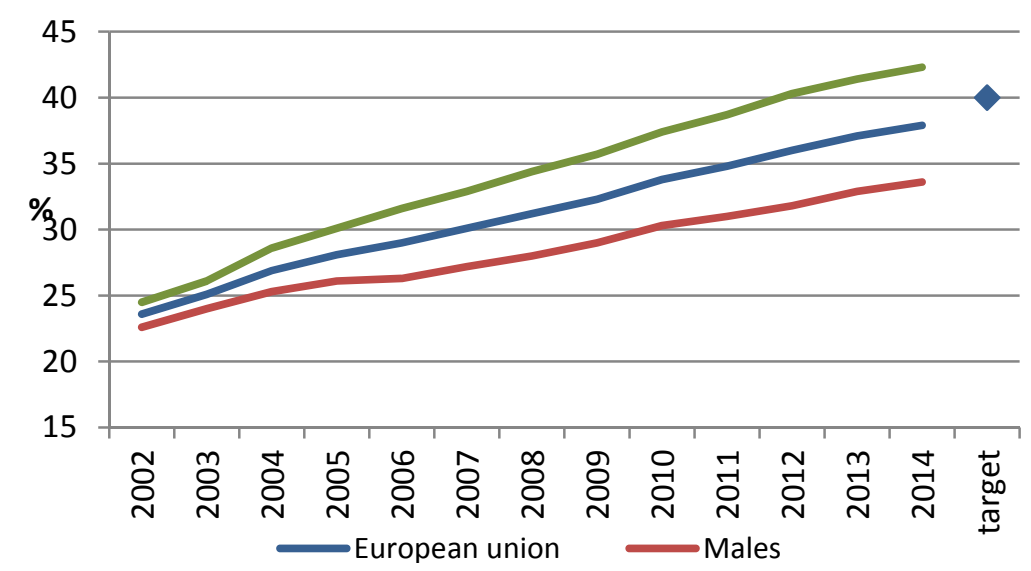

Figure 6. Evolution of the percentage of the population aged $30-34$ years with tertiary degree in the European Union

Source: compiled by authors according to data from Eurostat.

Figure 7 shows the differences in the evolution of the indicator between member countries in 2002 and 2014 and compares the values with the target values of countries that should be achieved no later than 2020. As in the previous sub-objective, also in this case, are for each country national targets appropriate to the conditions and development of the country in previous periods. 


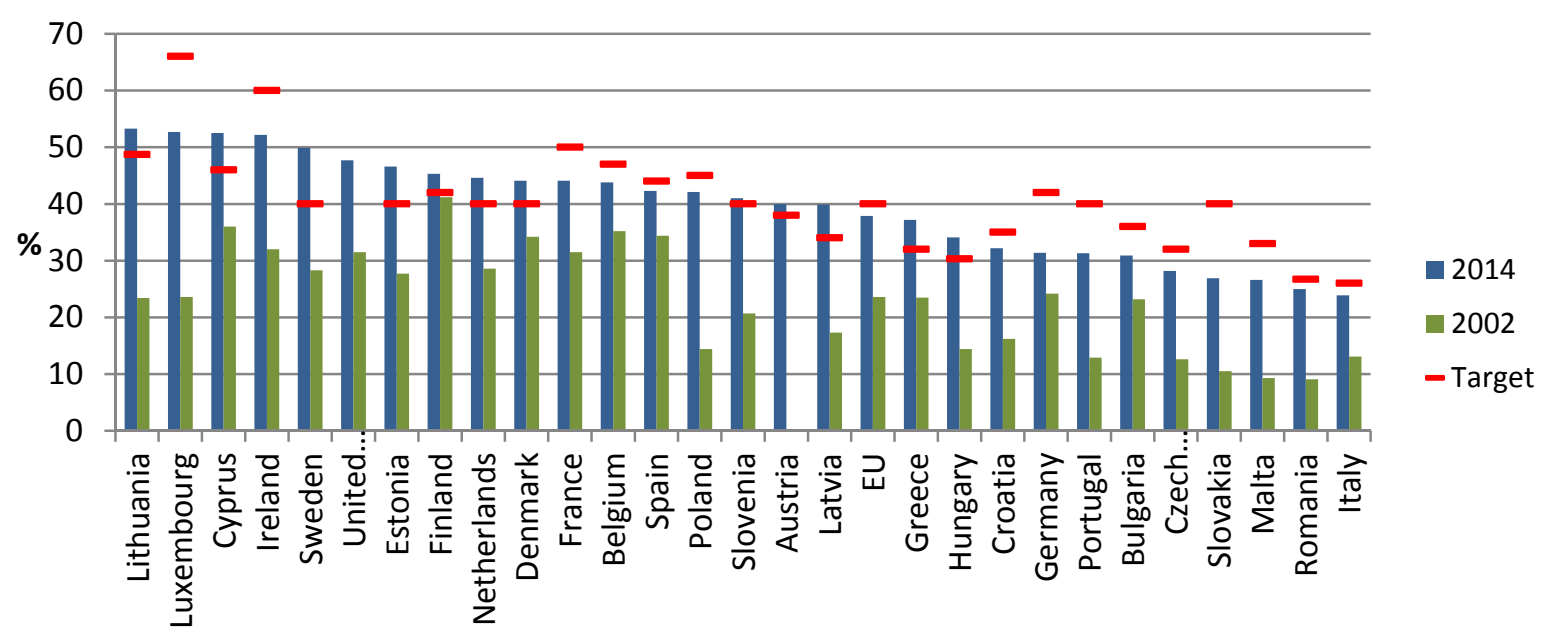

Figure 7. Percentage of population aged $30-34$ years with a tertiary education in EU Member States in 2002, 2014, compared with a target value

Source: compiled by authors according to data from Eurostat.

In 2014 was the highest percentage of people with tertiary education in Lithuania (53.3\%) and Luxembourg (52.7\%). More than half of people aged 30 to 34 years have a tertiary education in Cyprus and Ireland. By contrast, the lowest share of university graduates is in Italy (23.9\%), Romania (25.0\%) and Malta (26.6\%). At the end of the scale are also Slovakia, Czech Republic, Bulgaria and Portugal.

Lithuania and Luxembourg are also countries that over the past thirteen years recorded the largest increase in this indicator, nearly 30.0\%. They are followed by Poland, whom indicator rose from $14.4 \%$ to $42.1 \%$ and Latvia with a $22.6 \%$ increase. Comparing the obtained values of the monitored indicator in 2014 with the targets we find that most behind the target is Luxembourg and Slovakia (more than 13.0\%). They are followed by Germany, Portugal and Ireland. Positive is the fact, that 12 member countries in 2014 exceeded its target. The best is Sweden, which has $9.9 \%$ more people with tertiary education compared to the target, then Estonia (6.6\%), Cyprus (6.5\%), Latvia (5.9\%) and Greece (5.2\%).

Figure 8 shows the evolution of the percentage of the population aged 30-34 years with tertiary degree in the southern countries of European Union on the total population monitored age group from 2002 to 2014.Since the beginning of the period until 2014 just three countries reached the target values of the monitored indicator. Cyprus is one of the compared countries, which already in 2006 achieved objective (46.0\%) and in 2014 even exceed the value by $6.5 \%$. Greece and Slovenia have fulfilled their objectives between the years 2013 and 2014. Remaining six monitored countries - Portugal, Malta, Bulgaria, Croatia, Italy and Spain did not fulfill yet their target values. Spain is the nearest to achieve the target (44.0\%) and needs to increase the current value by $1.7 \%$. On the contrary, Portugal lags behind the target (40.0\%) of $8.7 \%$. 


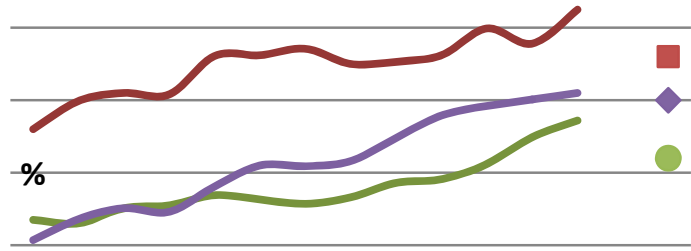

Cyprus Greece Slovenia

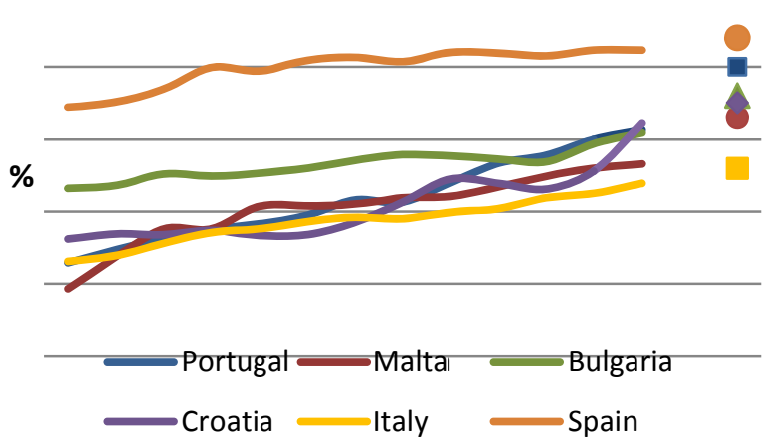

Figure 8. Development of the percentage of the population aged 30-34 years with tertiary education in the southern countries of the European Union Source: compiled by authors according to data from Eurostat.

As indicated above, six of the monitored countries still do not achieve the target values. Therefore, Figure 9, Table 3 and Table 4 show the estimated development of the indicator in all these countries by 2020 so that they achieve the target.
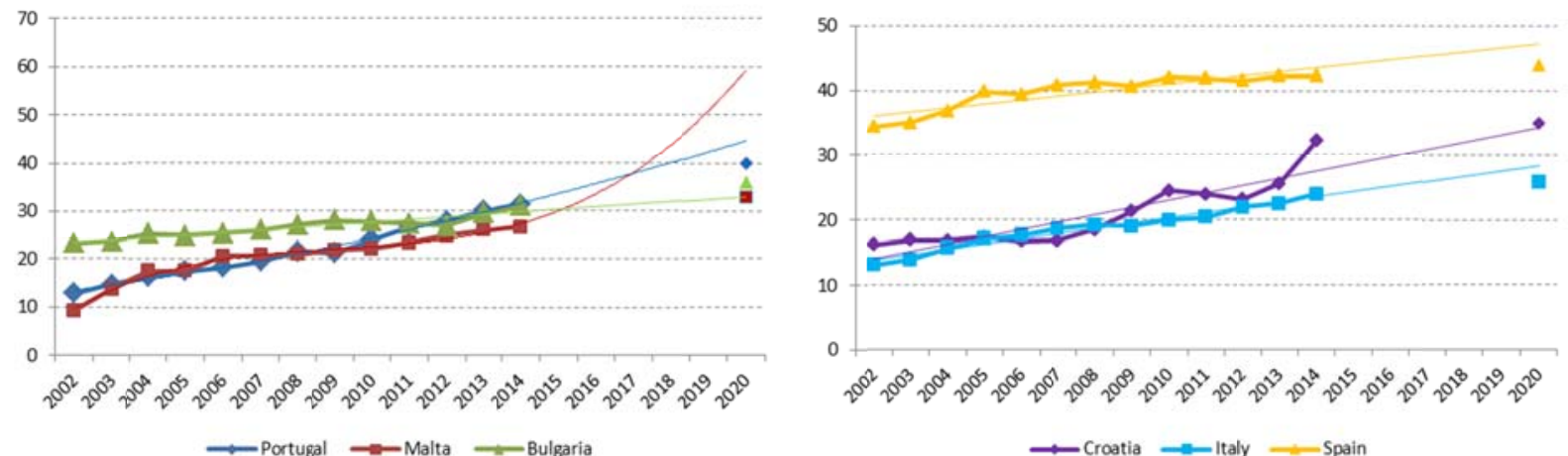

Figure 9. Estimated development of indicator by 2020

Source: compiled by authors.

Table 3. The estimated parameters of the regression model II

\begin{tabular}{|c|c|c|c|c|c|c|c|c|c|c|c|c|}
\hline & $\begin{array}{c}\text { Multiple } \\
\mathrm{R}\end{array}$ & $\begin{array}{c}\mathrm{R} \\
\text { Square }\end{array}$ & $\begin{array}{c}\text { Adjusted } \\
R \\
\text { Square }\end{array}$ & $\begin{array}{c}\text { Stand. } \\
\text { Error }\end{array}$ & Significance F & & Coefficients & $\begin{array}{l}\text { Stand. } \\
\text { Error }\end{array}$ & t Stat & $P$-value & $\begin{array}{c}\text { Lower } \\
95 \%\end{array}$ & $\begin{array}{l}\text { Upper } \\
95 \%\end{array}$ \\
\hline \multirow{3}{*}{ Portugal } & \multirow{3}{*}{0.9953} & \multirow{3}{*}{0.9907} & \multirow{3}{*}{0.9888} & \multirow{3}{*}{0.6251} & \multirow{3}{*}{ 7.10323E-11 } & Intercept & 12.4776 & 0.6118 & 20.395 & $1.77 \mathrm{E}-09$ & 11.114 & 13.841 \\
\hline & & & & & & XVar. 1 & 0.9759 & 0.2010 & 4.855 & 0.000666 & 0.528 & 1.424 \\
\hline & & & & & & XVar. 2 & 0.0377 & 0.0140 & 2.700 & 0.02233 & 0.007 & 0.069 \\
\hline \multirow{4}{*}{ Malta } & \multirow{4}{*}{0.9909} & \multirow{4}{*}{0.9818} & \multirow{4}{*}{0.9757} & \multirow{4}{*}{0.7640} & \multirow{4}{*}{$9.85127 \mathrm{E}-07$} & Intercept & 4.9434 & 1.1658 & 4.240 & 0.002173536 & 2.306 & 7.581 \\
\hline & & & & & & $\overline{X \text { Var. } 1}$ & 5.4323 & 0.6944 & 7.823 & $2.64612 \mathrm{E}-05$ & 3.861 & 7.003 \\
\hline & & & & & & XVar. 2 & -0.6108 & 0.1131 & -5.401 & 0.000432515 & -0.867 & -0.355 \\
\hline & & & & & & XVar. 3 & 0.0250 & 0.0053 & 4.701 & 0.001118133 & 0.013 & 0.037 \\
\hline \multirow{2}{*}{ Bulgaria } & \multirow{2}{*}{0.9374} & \multirow{2}{*}{0.8787} & \multirow{2}{*}{0.8677} & \multirow{2}{*}{0.7963} & \multirow{2}{*}{ 2.27101E-06 } & Intercept & 22.8808 & 0.4685 & 48.836 & $3.26 \mathrm{E}-14$ & 21.850 & 23.912 \\
\hline & & & & & & XVar. 1 & 0.5269 & 0.0590 & 8.927 & $2.27 \mathrm{E}-06$ & 0.397 & 0.657 \\
\hline \multirow{2}{*}{ Croatia } & \multirow{2}{*}{0.8989} & \multirow{2}{*}{0.8079} & \multirow{2}{*}{0.7905} & \multirow{2}{*}{2.2263} & \multirow{2}{*}{$2.94466 \mathrm{E}-05$} & Intercept & 12.9038 & 1.3098 & 9.852 & $8.58203 \mathrm{E}-07$ & 10.021 & 15.787 \\
\hline & & & & & & XVar. 1 & 1.1225 & 0.1652 & 6.802 & $2.94466 \mathrm{E}-05$ & 0.759 & 1.486 \\
\hline \multirow{2}{*}{ Italy } & \multirow{2}{*}{0.9838} & \multirow{2}{*}{0.9680} & \multirow{2}{*}{0.9650} & \multirow{2}{*}{0.6014} & \multirow{2}{*}{ 1.4416E-09 } & Intercept & 12.9808 & 0.3538 & 36.686 & 7.44E-13 & 12.202 & 13.760 \\
\hline & & & & & & XVar.1 & 0.8126 & 0.0446 & 18.229 & 1.44E-09 & 0.715 & 0.911 \\
\hline \multirow{2}{*}{ Spain } & \multirow{2}{*}{0.8881} & \multirow{2}{*}{0.7888} & \multirow{2}{*}{0.7696} & \multirow{2}{*}{1.3045} & 5012735 & Intercept & 35.5538 & 0.7675 & 46.325 & $5.80459 E-14$ & 33.865 & 37.243 \\
\hline & & & & & $5.012 / 3 E-05$ & XVar. 1 & 0.6198 & 0.0967 & 6.410 & $5.01273 \mathrm{E}-05$ & 0.407 & 0.833 \\
\hline
\end{tabular}

Source: compiled by authors. 
For a description of the estimated development, we have worked with several functions (exponential, logarithmic, linear, and other) and for the most appropriate function we selected function with the highest coefficient of Determination, Significance F and Pvalues (Table 3). The most appropriate trend of estimated development of indicator in Bulgaria, Croatia, Italy and Spain is a linear trend. For Portugal is the most accurate trend of estimated development of indicator the polynomial trend of 2nd range, for Malta the polynomial trend of 3rd range (Table 4).

Table 4. Trends describing estimated development of the monitored indicator by 2020

\begin{tabular}{lll}
\hline Country & Trend & $\mathrm{R}^{2}$ \\
\hline Portugal & $\mathrm{y}=0.0377 \mathrm{x}^{2}+0.9759 \mathrm{x}+12.4776$ & 0.9907 \\
\hline Malta & $\mathrm{y}=0.0250 \mathrm{x}^{3}-0.6108 \mathrm{x}^{2}+5.4323 \mathrm{x}+4.9434$ & 0.9818 \\
\hline Bulgaria & $\mathrm{y}=0.5269 \mathrm{x}+22.8808$ & 0.8787 \\
\hline Croatia & $\mathrm{y}=1.1225 \mathrm{x}+12.9038$ & 0.8079 \\
\hline Italy & $\mathrm{y}=0.8126 \mathrm{x}+12.9808$ & 0.9680 \\
\hline Spain & $\mathrm{y}=0.6198 \mathrm{x}+35.5538$ & 0.7888 \\
\hline
\end{tabular}

Source: compiled by authors.

If the value of the indicator in selected countries develope by the trend in Table 4, Spain is expected to reach target value expressing the share of the population with a tertiary degree at age 30-34 years in the total population of that age group already in 2015 (44.23\%). Malta should achieve the target in 2016 (33.46\%), Italy in 2018 (26.8\%) and Portugal in 2019 (42.26\%). On this basis, we can conclude that if the indicator develops in the future according to the above functions, Bulgaria and Croatia would not achieve their national targets even by 2020. However, Croatia should be closer to the target and its value in 2020 would be $34.23 \%$, while the target is $35 \%$.

\section{Conclusion}

The article deals with one of the objectives of the Europe 2020 strategy, and that is education. The measures such as counseling, mentoring, various forms of scholarships and support programs, measures relating to truancy and many others should be taken as the prevention of early school leaving. The counseling is one of the key strategies for eliminating early school leaving, which can help young people find their place in increasingly complex educational systems, but also to provide relevant information for right decisions about a future career. In attaining the sub-target for early leaving of education and training in the European Union achieves the best results Latvia, which value in 2014 is lower than the stated objective. Conversely, the worst value of this indicator reached Malta. Ultimately, the positive is fact, that the number of countries, which already achieved the sub-objective rise from 8 countries in 2013 to 16 countries in 2014. As for the southern countries of European Union, Cyprus, Croatia, Italy, Greece and Slovenia achieved the stated objectives during monitored period, whereby the best value is reached by Slovenia, whose criterion has already been achieved in 2003 for the first time. Already mentioned Malta, with Portugal, Spain and Bulgaria are lagging behind in achieving that objective throughout whole monitored period. We used regression analysis to model the estimated development of the indicator in these four countries. The suitability of trend function was checked by the Coefficient of Determination, 
F test and the P-value. According to this, all countries should achieve their national target until the year 2020 .

The second study area was focused on tertiary education. More graduates have a positive impact on increasing labor productivity and consequently on economic growth of the country. Therefore, the education policy in individual countries should be adapted to the requirements of the labor market. Also, the formation of clusters is very important for the development of mutual communication and cooperation between universities and employers, and consequently for a deeper and specific knowledge of the possibilities of higher education and the labor market needs.The highest value has Lithuania and Luxembourg, while the lowest Italy and Romania. Lithuania and Cyprus are the countries where more than $50 \%$ of the population aged 30 - 34 years in 2014 had a tertiary education and also it already reached its target value. From the southern countries of European Union Portugal, Malta, Bulgaria, Croatia, Italy and Spain are still below the target. Portugal is most lagging behind target. Also in this case was using regression analysis to model the future development of the indicator and the suitability of trend function was checked by the Coefficient of Determination, F test and the P-value. Based on this, Croatia and Bulgaria would not achieve their national targets even by 2020.

\section{References}

Çolak, M. S., Ege, A. (2013), An Assessment of EU 2020 Strategy: Too Far to Reach? Social Indicators Research, New York: Springer. 110(2). pp. 1-22.

Dolinská, V. (2014), Vzdelávanie dospelých v kontexte celoživotného vzdelávania, Vzdelávanie ako determinant rozvoja sociálneho podnikania. Zborník vedeckých štúdií. Ekonomická fakulta Univerzity M. Bela, 2014. pp.1-11, ISBN 978-80-557-0748-8.

Dudová, I. (2009), Ekonómia vzdelávania. Bratislava: Vydavatel’stvo EKONÓM, 168 s., ISBN 978-80-225-2750-7.

European Commission (2010), Europe 2020, A strategy for smart, sustainable and inclusive growth, Available at http://eurlex.europa.eu/LexUriServ/LexUriServ.do?uri=COM:2010:2020:FIN:EN:PDF.

European Commission (2013), Smarter, Greener, more Inclusive? - Indicators to Support the Europe 2020 Strategy, Available at http://epp.eurostat.ec.europa.eu/cache/ITY_OFFPUB/KS-02-13-238/EN/KS-02-13-238EN.PDF.

European Commission (2014a), Europe 2020 indicators, Available at http://epp.eurostat.ec.europa.eu/portal/page/portal/europe_2020_indicators/headline_ind icators.

European Commission (2014b), Europe 2020: Europe's growth strategy, Available at http://ec.europa.eu/europe2020/pdf/europe_2020_explained.pdf.

European Commission (2015a), Eurostat, Available at http://ec.europa.eu/eurostat.

European Commission (2015b), The EU is moving closer to its Europe 2020 goals on education, Available at http://ec.europa.eu/eurostat/documents/2995521/6787423/320042015-BP-EN.pdf/b2f295ba-2e15-409c-bec9-91c4e49c5d32.

Hobza, A., Mourre, G. (2010), Quantifying the potential macroeconomic effects of the Europe 2020 strategy: stylised scenarios, Economic Papers 424. Brussels: Economic and Financial Affairs, available at: http://ec.europa.eu/economy_finance/publications/economic_paper/2010/pdf/ecp424_en .pdf .

Leschke, J., Theodoropoulou, S., Watt, A. (2012), How do economic governance reforms and austerity measures affect inclusive growth as formulated in the Europe 2020 Strategy? 

In: S. Lehndorff (ed.) (2012), A triumph of failed ideas: European models of capitalism in the crisis, Brussels: ETUI, pp. 243.

Marlier, E., Natali, D. (eds.) (2010), Europe 2020: Towards a More Social EU? New York: Peter Lang Publishing Group.

Matulčíková, M., Matulčík, J. (2012), Vzdelávanie a kariéra, Bratislava: Vydavatel'stvo EKONÓM, 256 s, ISBN 978-80-225-3472-7.

Ministry of finance of Slovak Republic (2005), Stratégia konkurencieschopnosti Slovenska do roku 2010, Národná lisabonská stratégia, 2005, available at: http://www.rokovania.sk/appl/material.nsf/0/94ECDFEF0E61564AC1256FA50033DF B9/\$FILE/Zdroj.html.

Roth, F., Thum, A.-E. (2010), The Key Role of Education in the Europe 2020 Strategy, Economic Policy, CEPS Working Documents. Brussels: CEPS, pp. 17. 